\title{
Evaluation of the antimicrobial and antioxidant activities of essential oils, extracts and their main components from oregano from Madeira Island, Portugal
}

\author{
Paula C. Castilho*, Sonia Savluchinske-Feio, Tatiana S. Weinhold, Sandra C. Gouveia \\ Centro de Química da Madeira, Universidade da Madeira, Campus da Penteada, 9000-390 Funchal, Portugal
}

\section{A R T I C L E I N F O}

\section{Article history:}

Received 16 February 2011

Received in revised form

9 August 2011

Accepted 18 August 2011

\section{Keywords:}

Origanum

Extracts

Essential oils

Antimicrobial

Antioxidant

\begin{abstract}
A B S T R A C T
Origanum vulgare subsp. virens growing wild in Madeira Island, Portugal was studied within the ongoing investigations on polymorphic Lamiaceae species. The antimicrobial activity of the essential oils and $n$-hexane extracts of origanum was determined against 10 strains of bacteria and yeasts, found as human pathogenic or food spoilage microorganisms. The essential oils, $n$-hexane extracts and isolated compounds showed moderately activity, compared to standard antibiotics, inhibiting all tested bacteria except Pseudomonas aeruginosa. The most sensitive microorganism was Mycobacterium smegmatis, reaching $\mathrm{MIC}=25 \mu \mathrm{g} \mathrm{mL}{ }^{-1}$. The results obtained suggest a potential application of these oils in preventing the human pathogenic and food spoilage due to microorganism's growth. The essential oils and $n$-hexane extracts have greater RSC than polar extracts, probably due to the high contents in thymol, which demonstrated the highest activity in the DPPH assay. All studied origanum samples showed a large content in non-esterified 1-hexacosanol, $\mathrm{C}_{26} \mathrm{H}_{54} \mathrm{O}$, accumulated mainly in bracts and flowers.
\end{abstract}

(c) 2011 Elsevier Ltd. All rights reserved.

\section{Introduction}

Origanum vulgare L. subsp. virens (Hoffmanns. \& Link) Ietswaart (sometimes called the Moroccan origanum) is the common oregano that thrives naturally in almost every region of Portugal, especially on the edges of fields, on dry and uncultivated or waste ground. In Madeira Island, it is very common in the edges on paths in the Laurisilva forest, up to $1500 \mathrm{~m}$ of altitude.

The antimicrobial properties of volatile aromatic oils and medium-chain fatty acids derived from edible plants have been recognized since antiquity. Origanum oil, used as food-flavouring agent, possesses a broad spectrum of antimicrobial activity due, at least in part, to its high content of phenolic derivatives, such as carvacrol and thymol (Preuss et al., 2005) In the literature, there are many reports relating the chemical composition and the antimicrobial properties of the essential oils of various origanum species, and their application in various commercial preparations, as antimicrobials and antioxidants (Baydar, Sagdic, Ozkan, \& Karadogan, 2004; Kulisic, Radonic, Katalinic, \& Milos, 2004).

\footnotetext{
* Corresponding author. Centro de Química da Madeira, Universidade da Madeira, Campus da Penteada, piso 0, 9000-390 Funchal, Portugal Tel.: +351 291705102; fax: +351291705149.

E-mail address: castilho@uma.pt (P.C. Castilho).
}

Earlier studies have demonstrated the ability of origanum oil to retard and to inhibit the growth of various food spoiling organisms including the species of Aspergillus (mycotoxinogenic filamentous fungi) and industrial yeasts. Origanum oil completely inhibited the growth of Candida albicans at $0.25 \mathrm{mg} \mathrm{mL}^{-1}$, being the most potent of the essential oils tested and proved to be bactericidal in culture to two strains of Staphylococcus aureus at $0.25 \mathrm{mg} \mathrm{mL}^{-1}$ (Salgueiro et al., 2003). However, the antimicrobial activity is strongly dependent on composition and origanum shows a wide variety of subspecies with various chemotypes within each of those, rendering it difficult to compare results from different bibliographic sources. According to Chorianopoulos et al. (2004), the antimicrobial activity of origanum essential oil depends greatly on the chemical composition in carvacrol and thymol.

The current trend adopted by food production, legislative offices and consumers has demanded a progressive retreat of chemical additives in food conservation systems, searching alternative substances in order to preserve final products from food spoilage and diseases caused by microorganisms and oxidation.

The present work was undertaken to determine the chemical composition of essential oils from origanum growing wild in several locations of Madeira Island, and to evaluate any relationships between composition and the radical scavenging capacity and the antimicrobial activity towards human pathogenic and food spoilage fungi and bacteria, in the search for alternative to commercial preservatives. 


\section{Materials and methods}

\subsection{Plant material}

O. vulgare subsp. virens samples were collected in four locations of Madeira Island, Portugal, between 500 and $1000 \mathrm{~m}$ of altitude. Samples are designated from 1 to 4 , collected respectively at Calheta, Encumeada, Ponta do Sol and Santo da Serra. Aerial parts were dried in well ventilated spaces away from sun light. Vouchers were included on the collection of Madeira Botanical Gardens (MADJ306106, MADJ306206, MADJ306306, MADJ306406).

\subsection{Essential oils isolation}

Air-dried plant materials were submitted hydrodistillation according to European Pharmacopea, using a Clevenger type apparatus. The essential oils amounts were determined gravimetrically.

\subsection{Essential oils analysis}

Chromatographic analysis was carried out on a Hewlett Packard 5890 series II GC equipped with an Automatic Sampler HP 6890 series injector linked to two injector modules, two flame ionization detectors and two columns, together with a computer station for data treatment. The columns were an OV-101 fused silica (50 $\mathrm{m} \times 0.25 \mathrm{~mm}, 0.25 \mu \mathrm{m}$ film thickness) and Supelcowax 10 (30 $\mathrm{m} \times 0.25 \mathrm{~mm}, 0.25 \mu \mathrm{m}$ film thickness). Oven temperature was held at $70^{\circ} \mathrm{C}$ for $5 \mathrm{~min}$ and then programmed to $230^{\circ} \mathrm{C}$ at a rate of $2{ }^{\circ} \mathrm{C} / \mathrm{min}$ with a split ratio of 1:45. The detector and injector were kept at $250{ }^{\circ} \mathrm{C}$ and $240{ }^{\circ} \mathrm{C}$, respectively. Pure helium was used as carrier gas, at constant pressure $55 \mathrm{kPa}$ for the OV-101 and $45 \mathrm{kPa}$ for the Supelcowax 10. A $1 \mu \mathrm{l}$ of oil was injected. Identification of compounds was based on their mass spectra and their retention indices (RI) obtained from calculated values relative to $C_{8}-C_{20}$ $n$-alkanes. The intensity of each peak was integrated. Each sample was analysed three times. The average peak areas of all GC signals were determined and the percentage of each component peak was calculated by comparing its average area to the total area. The GC-MS analysis for identification of compounds was carried out in a Varian Saturn 3 GC-MS (Ion trap) operating in EI mode and using an HP-5MS column $(30 \mathrm{~m} \times 0.25 \mathrm{~mm}, 0.25 \mu \mathrm{m}$ film thickness), carrier gas helium, constant pressure $90 \mathrm{kPa}$, split 1:20. The oven was programmed initially from $70^{\circ} \mathrm{C}$ with $2 \mathrm{~min}$ hold up time to the final temperature of $230{ }^{\circ} \mathrm{C}$ with $5{ }^{\circ} \mathrm{C} / \mathrm{min}$ ramp. The final temperature hold time was $5 \mathrm{~min}$. The inlet and GC/MS interface temperatures were kept at $250^{\circ} \mathrm{C}$ and $280^{\circ} \mathrm{C}$, respectively. The temperature of El $70 \mathrm{eV}$ source was $200^{\circ} \mathrm{C}$ with full scan $(25-450 \mathrm{~m} / \mathrm{z})$, scan time $0.3 \mathrm{~s}$. The mass spectra of essential oil and extract components were identified by comparing the mass spectra of the analytes with those of authentic standards from the mass spectra of Wiley 6.0 and Mass Spectra Library (NIST 98), and with corresponding data of components from reference oils analysed in our laboratory.

\subsection{Preparation of extracts}

The air-dried powdered aerial parts were successively extracted at room temperature with $n$-hexane, chloroform, ethyl acetate and methanol. Chlorophylls were removed with activated charcoal and the solvents evaporated under reduced pressure, at room temperature. During the solvent evaporation of the $n$-hexane extracts of all plant materials, white crystals of melting point $77-78{ }^{\circ} \mathrm{C}$ were formed. These were filtered and characterized, being identified as pure $n$-hexacosanol (ceryl alcohol) by FTIR, mass spectrometry and NMR.

\subsection{Antioxidant activity}

Free Radical Scavenging Capacity (RSC). The RSC was evaluated by measuring the scavenging activity of the examined essential oils, extracts and pure predominant compounds on 2,2-diphenyl-1picrylhydrazyl (DPPH) radicals.

The DPPH assay was performed as previously described in the literature (Gordon, Paiva-Martins, \& Almeida, 2001). Briefly, 5 solutions of Trolox (concentrations ranging from 0.005 to $0.025 \mu \mathrm{M}$ ) were made to react with DPPH and used to establish a calibration curve. The disappearance of DPPH colour was read spectrophotometrically at $515 \mathrm{~nm}$ using a Perkin-Elmer Lambda 2 spectrophotometer. The samples (accurately weighted) were mixed with $1 \mathrm{~mL}$ of $90 \mu \mathrm{M}$ DPPH solution and the volume was adjusted to $4 \mathrm{~mL}$ with $\mathrm{MeOH}$ p.a. For each sample, the absorbance of four replicates was recorded. The RSC is expressed as $\mu \mathrm{mol}$ eq. Trolox/ $100 \mathrm{~g}$ of extract using the regression equation, obtained from the calibration curve:

$y=-10.63 x+0.4701\left(R^{2}=0.9978\right)$

\subsection{Microorganisms}

All strains were obtained from the Culture Collection of Industrial Microorganisms (CCMI) Laboratório de Microbiologia Industrial, Lisbon, Portugal.

Bacteria: Escherichia coli CCMI 270, Listeria monocytogenes CCMI 1106 Micrococcus luteus CCMI 322, Mycobacterium smegmatis CCMI 690, Pseudomonas aeruginosa CCMI 331, S. aureus CCMI 335, Streptococcus faecium CCMI 338. Yeasts: C. albicans CCMI 209, Debaryomyces klockeri CCMI 157 (Synonym of Debaryomyces hansenii (Zopf) Lodder E Kreger-van Rij var. hansenii), Rhodotorula rubra CCMI 43. Rhodotorula mucilaginosa is the current name for the species $R$. rubra (Bennett, 1990) but in this work the name registered in the collection will be referred.

\subsubsection{Incubation conditions}

Brain Heart Infusion (Merck, Darmstadt, Germany) was used as culture medium for bacteria, whereas Malt Extract Agar (Merck, Darmstadt, Germany) was used for yeasts.

The temperature and incubation time were variable according to the microorganism requirements. M. luteus was incubated at $30^{\circ} \mathrm{C}$ for $24 \mathrm{~h}$. C. albicans was incubated $30^{\circ} \mathrm{C}$ for $48 \mathrm{~h}$ whereas Debaryomyces kloeckeri and R. rubra were incubated for $72 \mathrm{~h}$ at $30^{\circ} \mathrm{C}$. The other microorganisms were incubated at $37^{\circ} \mathrm{C}$ for $24 \mathrm{~h}$.

\subsubsection{Screenings for antimicrobial activities}

The antimicrobial activity of the compounds was determined by the broth/agar dilution methods (Muroi \& Kubo, 1996), accordingly to the CLSI (formerly NCCLS) protocols (NCCLS 1997, NCCLS 2003).

The following concentrations were tested: $200,100,50,25$, and $12.5 \mu \mathrm{g} \mathrm{mL} \mathrm{m}^{-1}$. A suspension of each microorganism $\left(10^{5}\right.$ cell $\left./ \mathrm{mL}\right)$ was obtained by measuring optical density at $620 \mathrm{~nm}$ using a Lambda 2 Perkin Elmer spectrophotometer. $1 \mathrm{~mL}$ portions of the culture media were placed in the test tubes to which the successive dilutions of the oils/extracts samples were added; $20 \mu \mathrm{L}$ of the cell suspensions were added to those mixtures. After incubation for $24 \mathrm{~h}-48 \mathrm{~h}$ for bacteria, at $37^{\circ} \mathrm{C}$ the microbial growth was examined. The same procedure was performed for yeasts, except that $D$. kloeckeri and $R$. rubra were incubated for $72 \mathrm{~h}$. The results are expressed in Minimal Inhibitory Concentration (MIC), the weakest concentration of the samples yielding no visible growth. The bactericidal/fungicidal activities were determined by a sub-cultivation of the samples into normal culture media at appropriate temperature and incubation times (Benites et al., 2009). 
5-Fluorocytosine (Sigma, Steinheim, Germany) was used as a synthetic antimycotic for a positive control, whereas Rifampicin (Sigma, Steinheim, Germany) was used as antibiotic positive control. The MIC of each compound was determined at least twice. Essential oils and $n$-hexane extracts from collections 1 to 4 were used in this study. Sample 3b was used in this work, i.e., essential oil and $n$-hexane extract of flowers of the plants collected at location 3 . For simplicity, they will be referred to as sample 3 throughout this work. The essential oils and $n$-hexane extracts were dissolved in dimethylsulphoxide (DMSO) (Merck, Darmstadt, Germany). The predominant compounds thymol, carvacrol, methyl-carvacrol, $p$ cymene and $\gamma$-terpinene were also tested in the conditions described above.

\section{Results and discussion}

\subsection{Chemical composition of the essential oil}

Wild plants were collected in June 2006, in several locations of Madeira Island in zones of protection of the Laurisilva forest, characterized by high rainfall and high relative humidity, between 500 and $1000 \mathrm{~m}$ of altitude. Some variations in plant maturation were found, even though a direct correlation with altitude, humidity or sun light exposure was not possible to establish. Plants collected at Calheta and Santo da Serra (sample 1 and 4) had a much lower proportion of flowers (actually, bracts and flowers) to leaves than the other collections.

The content of the essential oils, expressed in mg of essential oil/ $100 \mathrm{~g}$ dried plant, is presented on Table 1.

Table 2 shows the list of chemical components of the investigated essential oils and their relative amounts, expressed as percentages. Major components are highlighted on that table. The yield shows variations which reflect the proportion of flowers to leaves on the analysed samples. By separating one of the collections (3) into leaves and flowers ( $3 a$ and $3 b$, respectively), we found that essential oil accumulates mainly in the flowers. The same tendency was found for 1-hexacosanol isolated from the $n$-hexane extracts (Table 1). This compound represents the main difference between essential oils and $n$-hexane extracts. After its removal by precipitation, the respective chromatograms are very much alike. The composition of two of those extracts (from samples 1 and 2 ) is also presented in Table 2.

Data for typical essential oil contents and composition of $O$. vulgare subsp. virens are not abundant, although recently several papers related to this subspecies were published. Ferreira et al. (1998) refer that $O$. vulgare subsp. virens essential oil is not rich in carvacrol. However, Salgueiro et al. (2003) studied a carvacrol rich O. vulgare subsp. virens and its activity on C. albicans.

It has been pointed out (Figueredo, Cabassu, Chalchat, \& Pasquier, 2006) that there are significant differences in the yield and composition of essential oils from populations of $O$. vulgare subsp. virens arising from environment factors, the most important of those being altitude, relating this to lack of water and short growing periods. Studies on 0 . vulgare subsp. virens letswaart from Italy, France and Portugal revealed markedly different chemical

Table 1

Plant contents in essential oil and $n$-hexacosanol.

\begin{tabular}{lll}
\hline Collection & $\begin{array}{l}\text { mg essential oil/100 g } \\
\text { dried plant }\end{array}$ & $\begin{array}{l}\text { mg hexacosanol/100 g } \\
\text { dried plant }\end{array}$ \\
\hline 1 & 890 & 111.18 \\
2 & 1730 & 252.72 \\
3 & 2410 & 251.07 \\
4 & 700 & 48.65 \\
\hline
\end{tabular}

Table 2

Chemical composition of essential oils (EO), expressed as percentages, obtained by hydrodistillation of aerial parts of Origanum vulgare subsp. virens from Calheta (1), Encumeada (2), Ponta do Sol (3) and Santo da Serra (4). The chemical composition of hexane extracts (Hex) is presented for samples 1 and 2 .

\begin{tabular}{|c|c|c|c|c|c|c|c|c|}
\hline \multirow[t]{2}{*}{ Compounds } & \multirow[t]{2}{*}{ RIa } & \multirow[t]{2}{*}{ RIp } & \multicolumn{2}{|l|}{1} & \multicolumn{2}{|l|}{2} & \multirow{2}{*}{$\frac{3}{E O}$} & \multirow{2}{*}{$\frac{4}{E O}$} \\
\hline & & & EO & Hex & EO & Hex & & \\
\hline$\alpha$-Thujene & 924 & 1029 & 1.3 & 1.08 & 0.34 & 0.47 & 0.4 & 0.63 \\
\hline$\alpha$-Pinene & 930 & 1030 & 0.42 & 0.63 & 0.22 & 0.24 & 0.19 & 0.32 \\
\hline 1-Octen-3-ol & 955 & 1147 & 1.1 & 0.47 & 0.39 & 0.53 & 0.3 & 1.21 \\
\hline Sabinene & 958 & 1123 & 0.2 & $\mathrm{v}$ & & 0.17 & $\mathrm{v}$ & 0.2 \\
\hline$\beta$-Pinene & 963 & 1124 & 0.2 & $\mathrm{v}$ & & $\mathrm{v}$ & $\mathrm{v}$ & $\mathrm{v}$ \\
\hline Myrcene & 975 & 1157 & 1.44 & 1.72 & 0.8 & 0.85 & 0.75 & 1.05 \\
\hline$\alpha$-Terpinene & 1002 & 1187 & 2.39 & 2.50 & 1.46 & 1.36 & 1.43 & 1.7 \\
\hline$p$-Cymene & 1003 & 1276 & 6.93 & 12.49 & 5.91 & 5.72 & 4.61 & 11.33 \\
\hline 1,8-Cineole & 1005 & 1206 & 0.35 & 0.48 & 0.28 & 0.25 & & \\
\hline Cis-b-ocimene & 1017 & 1236 & 5.34 & 6.10 & 0.58 & 1.14 & 0.56 & 2.51 \\
\hline Trans-b-ocimene & 1027 & 1236 & 0.65 & 0.22 & $\mathrm{~V}$ & 0.18 & 0.52 & 0.32 \\
\hline$\gamma$-Terpinene & 1035 & 1250 & 20.49 & 20.79 & 8.66 & 10.31 & 10.38 & 19.61 \\
\hline Trans sabinene hydrate & 1037 & 1540 & 0.28 & 0.25 & & & & $\mathrm{v}$ \\
\hline Terpinolene & 1064 & 1290 & 0.37 & $\mathrm{v}$ & & & & $\mathrm{v}$ \\
\hline Linalool & 1074 & 1544 & 0.83 & 0.46 & 0.22 & 0.27 & 0.23 & 0.38 \\
\hline Borneol & 1134 & 1696 & 0.19 & & 0.18 & $\mathrm{v}$ & $\mathrm{v}$ & 0.37 \\
\hline Terpinen-4-ol & 1148 & 1598 & 3.97 & & 1.05 & 1.07 & 0.78 & 1.61 \\
\hline$\alpha$-Terpineol & 1159 & 1692 & 0.21 & & & & & $\mathrm{v}$ \\
\hline Thymol methyl ether & 1208 & 1583 & 6.91 & 4.19 & 1.84 & 1.38 & 1.96 & 7.11 \\
\hline Carvacrol methyl ether & 1224 & 1583 & 4.36 & 2.85 & 4.13 & 2.91 & 2.89 & 1.19 \\
\hline Thymol & 1275 & 2180 & 19.37 & 13.38 & 55.0 & 50.3 & 58.0 & 30.96 \\
\hline Carvacrol & 1286 & 2212 & 1.39 & 0.45 & 6.75 & 2.86 & 1.14 & 1.36 \\
\hline$\beta$-Caryophyllene & 1414 & 1600 & 9.07 & 9.67 & 5.3 & 7.08 & 6.08 & 6.44 \\
\hline$\alpha$-Humulene & 1447 & 1660 & 1.26 & 2.77 & 0.8 & 1.06 & 0.91 & 0.9 \\
\hline$\gamma$-Muurolene & 1469 & 1684 & & & 0.54 & & 0.25 & \\
\hline Germacrene D & 1474 & 1684 & 3.54 & 6.40 & 0.34 & & 2.48 & 3.91 \\
\hline$\gamma$-Cadinene & 1500 & 1751 & 1.77 & 3.21 & 0.55 & 0.63 & 0.79 & 1.78 \\
\hline Calamenene & 1503 & & 0.17 & 0.52 & & & $\mathrm{v}$ & 0.29 \\
\hline Bisabolene & 1505 & & 3.54 & 4.39 & 3.13 & 5.05 & 4.96 & 2.01 \\
\hline$\delta$-Cadinene & 1509 & 1751 & 0.29 & 1.27 & 0.67 & 0.33 & 0.39 & 0.24 \\
\hline Spathulenol & 1551 & 2061 & 0.26 & & & & & 0.33 \\
\hline Caryophyllene oxide & 1561 & 1970 & 0.33 & 0.59 & & & & 0.34 \\
\hline Total & & & 98.92 & 97.1 & 99.18 & 98.98 & 100 & 98.1 \\
\hline Phenolic Compounds & & & 32.03 & 20.28 & 67.72 & 57.45 & 63.99 & 40.62 \\
\hline
\end{tabular}

RIa and RIp: retention índex relative to $C_{8}-C_{20} n$-alkanes in OV101 (apolar) and Supelcowax 10 (polar) column, respectively. Compounds are listed in order of elution in OV101 column. v: vestige, blank: not detected. Phenolic compounds percentages are highlighted in italic.

compositions. The main constituents of the Italian oil were linalool (10.1-70.1\%), $\beta$-caryophyllene (2.9-18.8\%), carvacrol (<0.1-13.7\%), terpinen-4-ol $(<0.1-15.5 \%)$ and $\alpha$-terpineol $(<0.1-68.3 \%)$ (Melegari et al., 1995); and of the French oil, thymol (3.7-9.6\%), $\beta$-caryophyllene (7.2-10.6\%), sabinene (6.5-11.8\%) and germacrene D (22.1-25.7\%). Oil from Portugal differed from the others by the presence of greater amounts of the non-functionalized hydrocarbons $\delta$-elemene (12.9\%), $\beta$-caryophyllene (11.1\%), $\alpha$-terpineol (9.2\%), germacrene B (6.6\%), (E)- $\beta$-ocimene $(6.6 \%)$ and $(Z)-\beta$-ocimene (3.7\%). Ferreira et al. (1998) reported differences in essential oil composition depending on light and temperatures. Most of these studies refer to Mediterranean climate and its variations.

In Madeira Island, with a subtropical climate, some of these considerations do not apply - altitude does not imply lack of water, always abundant, or light although it means a sharp decrease in average temperature. In general, it can be stated that all tested samples from $O$. vulgare subsp. virens growing wild in Madeira belong to a thymol rich chemotype. The most remarkable feature of these essential oils is their high contents in thymol methyl ether (1.84 up to 7.11) and carvacrol methyl ether (1.19-4.36\%). Indeed, all our oils were richer in carvacrol methyl ether than carvacrol itself. According to Figueredo et al. (2006) and references therein, nine Origanum species from the Mediterranean showed contents in these two ethers ranging from 0.1 to $0.5 \%$, trace in most samples. 
Only Hazzit, Baaliouamer, Faleiro, and Miguel (2006) refer to plants with noticeable amounts of these ethers: an Origanum floribundun with $6.9 \%$ of carvacrol methyl ether and a Thymus guyonii presenting $10.7 \%$ of thymol methyl ether. High levels of thymol methyl ether $(16.3 \%)$, and carvacrol methyl ether (11.4\%) were found in Origanum vulgare ssp. gladulosum from Algeria (Houmani, Azzoudj, Naxakis, \& Skoula, 2002). Satureja subspicata growing wild in Croatia presents $8.83 \%$ of thymol methyl ether and shows good antimicrobial activity despite the low levels of free phenols (Skocibusic, Bezic, \& Dunkic, 2006).

\subsection{Antioxidant activity}

In the DPPH assay, the ability of the investigated essential oils and extracts to act as donors of hydrogen atoms or electrons in transformation of DPPH radical into its reduced form DPPH was investigated. All of the assessed samples were able to reduce the stable, purple-coloured radical DPPH into yellow-coloured DPPH. Despite variations in composition, the RSC of the essential oils was not much different from each other, ranging from 249.35 to $263.64 \mu \mathrm{mol}$ eq. Trolox/100 g oil, and did not reflect the amount of phenolic components, to which the RSC is usually attributed (Table 3).

No direct correlation with each of free phenols, methylphenols or total phenolic compounds is possible even though the activity RSC of thymol is more than 10 fold the RSC of carvacrol, when the same method is applied to the pure compounds. The same trend was found by Yanishlieva et al. (1999) who used a different method, the autoxidation of purified triacylglycerols, to assess the antioxidant capacity of the two phenols. Thymol was found to be a much better antioxidant than carvacrol and the fact was attributed to the greater steric hindrance of the hydroxyl group of thymol. Kulisic et al. (2004) found similar RSC for both phenols in the DPPH method. In our study, the essential oils were less active than the extracts in $n$-hexane, but were more active than extracts in chloroform, ethyl acetate or even the rosmarinic acid rich methanol extract. The activities of the essential oils are around $250 \mu \mathrm{mol}$ eq. Trolox/100 g oil, while the values found for RSC of solvent extracts were $150 \pm 5$ for chloroform extracts, $120 \pm 3$ for ethyl acetate and $110 \pm 3 \mu \mathrm{mol}$ eq. Trolox/100 g for methanol.

\subsection{Antimicrobial activity}

The essential oils and $n$-hexane extracts of the four origanum collections were analysed for antimicrobial activity against $4 \mathrm{Gram}$ positive bacteria, 2 Gram-negative bacteria, 1 fast-acid bacterium and 3 yeasts. The antimicrobial activity of the compounds thymol, carvacrol, methyl-carvacrol, $p$-cymene and $\gamma$-terpinene present in the constitution of the essential oils was also evaluated. All essential oils, $n$-hexane extracts and the isolated compounds showed moderately activity when compared to the standard antibiotics (Tables 4 and 5). The essential oils did not differ remarkably in their activity against the tested microorganisms.

Table 3

Radical Scavenging Capacity of essential oils and $n$-hexane extract determined by the DPPH reaction.

\begin{tabular}{lll}
\hline Samples & RSC $(\mu \mathrm{mol}$ eq. \\
& Trolox $/ 100$ g EO $)$ & $\begin{array}{l}\text { RSC }(\mu \mathrm{mol} \text { eq. } \\
\text { Trolox } / 100 \text { g extract })\end{array}$ \\
\hline 1 & $249.35 \pm 1.24$ & $341.90 \pm 2.66$ \\
2 & $262.99 \pm 2.33$ & $327.84 \pm 1.34$ \\
3 & $263.64 \pm 1.76$ & - \\
4 & $259.31 \pm 1.12$ & - \\
\hline
\end{tabular}

There are some differences between the results obtained with the $n$-hexane extracts and the total essential oils, in several cases the extracts being unexpectedly more active than the essential oils.

For instance, the MICs of $25 \mu \mathrm{g} \mathrm{mL} \mathrm{m}^{-1}$ obtained for $n$-hexane extracts of samples 1 and 2 against $M$. smegmatis is much lower than that obtained for the respective essential oils (200 and $100 \mu \mathrm{g} \mathrm{mL}^{-1}$ ). Thymol showed the same activity, which suggests a correlation between this compound contents and M. smegmatis susceptibility. Pure methyl-carvacrol was also a very active compound.

The activity of all samples against the human pathogen, S. aureus seems to be related to the presence of thymol and carvacrol, both bactericidal at $100 \mu \mathrm{g} \mathrm{mL}^{-1}$. The other pure compounds were inactive. The MICs obtained with the $n$-hexane extracts are lower than those obtained with the isolated compounds, which suggests a synergistic effect.

The human pathogen $E$. coli, was inhibited by essential oils 2 and 3 and, by $n$-hexane extracts $1,2,3$ and 4 . Thymol and carvacrol showed bactericidal activity at $100 \mu \mathrm{g} \mathrm{mL}^{-1}$ and $\gamma$-terpinene was active at the higher concentration.

Thymol inhibited the growth of $P$. aeruginosa with cidal activity at $200 \mu \mathrm{g} \mathrm{mL} \mathrm{m}^{-1}$, but no inhibition was observed with the essential oils or the $n$-hexane extracts. In the present study, carvacrol was not active against $P$. aeruginosa. The results obtained with thymol may be considered very interesting, since that microorganism is very resistant even to rifampicin (MIC $=200 \mu \mathrm{g} \mathrm{mL}^{-1}$ ).

Recently, Cox and Markham (2007) studied the susceptibility and intrinsic tolerance of $P$. aeruginosa to carvacrol, terpinen-4-ol, $\alpha$-terpineol, citral, geraniol, linalool, trans-cinnamaldehyde and eugenol (but not thymol) finding that only carvacrol caused damage to the outer membrane of $P$. aeruginosa. The intrinsic tolerance of $P$. aeruginosa strains to those plant volatile compounds was associated with an active efflux mechanism and the barrier function of the outer membrane. A proton transfer mechanism based on the presence of its phenolic hydroxyl group has been proposed to explain the depolarizing actions of carvacrol (Ben Afra, Combes, Preziosi-Belloy, Gontard, \& Chalier, 2006; Ultree, Bennink, \& Moezelaar, 2002).

S. faecium showed no susceptibility to $\gamma$-terpinene and the other tested pure compounds were only bateriostatic at the maximum tested concentration, $200 \mu \mathrm{g} \mathrm{mL} \mathrm{m}^{-1}$. However, we observed bateriostatic activity of the $n$-hexane extracts at $100 \mu \mathrm{g} \mathrm{mL}^{-1}$, similar for all samples. For the essential oils, it was observed that samples 1 and 4, richer in phenols, have bactericidal activity, whilst samples 2 and 3, richer in hydrocarbons, have bacteriostatic activity at 100 and $50 \mu \mathrm{g} \mathrm{mL}^{-1}$, Synergism between essential oil components will be further explored.

The antimicrobial activity against the food spoilage Grampositive bacterium $M$. luteus, was detected for all essential oils and $n$-hexane extracts. Essential oil of samples 2 and 3 have bactericidal activity whereas, 4 , the one richer in $p$-cymene, presents bateriostactic activity, thymol and carvacrol showed bactericidal activity. Although $M$. luteus is non-pathogenic and usually regarded as a contaminant, it should be considered as an emerging nosocomial pathogen in immunocompromised patients. M. luteus is resistant to reduced water potential and can tolerate drying and high salt concentrations.

C. albicans is a harmless commensal yeast-like fungus in healthy humans which can cause systemic infections under immunecompromised individuals (Manohar et al., 2001). Thus, our interest in evaluate the potential of essential oils against this opportunistic microorganism. C. albicans was inhibited with fungicidal activity by $n$-hexane extracts of samples 3 and 4 at $200 \mu \mathrm{g} \mathrm{mL}$. Extracts of samples 1 and 2, and their essential oils were fungistatic at $200 \mu \mathrm{g} \mathrm{mL}^{-1}$. Carvacrol was found fungistatic at $50 \mu \mathrm{g} \mathrm{mL}^{-1}$. All other 
Table 4

Antimicrobial activity of Origanum essential oils and extracts.

\begin{tabular}{|c|c|c|c|c|c|c|c|c|}
\hline \multirow[t]{3}{*}{ Microorganisms } & \multicolumn{8}{|c|}{ Antimicrobial activity of Origanum essential oils and $n$-hexane extracts ( $\mu \mathrm{g} \mathrm{mL}^{-1}$ ) } \\
\hline & & \multirow{2}{*}{$\frac{1}{n \text {-Hexane }}$} & \multirow{2}{*}{$\frac{2}{\mathrm{EO}}$} & \multirow{2}{*}{$\frac{2}{n \text {-Hexane }}$} & \multirow{2}{*}{$\frac{3}{\mathrm{EO}}$} & \multirow{2}{*}{$\frac{3}{n \text {-Hexane }}$} & \multirow{2}{*}{$\frac{4}{\mathrm{EO}}$} & \multirow{2}{*}{$\frac{4}{n \text {-Hexane }}$} \\
\hline & & & & & & & & \\
\hline C. albicans & $>200$ & $200^{\mathrm{a}}$ & $200^{\mathrm{a}}$ & $100^{\mathrm{a}}$ & $200^{\mathrm{a}}$ & 200 & $>200$ & 200 \\
\hline D. kloeckeri & 200 & $100^{\mathrm{a}}$ & 100 & $50^{\mathrm{a}}$ & $100^{\mathrm{a}}$ & $100^{\mathrm{a}}$ & 100 & $100^{\mathrm{a}}$ \\
\hline E. coli & $>200$ & 200 & 200 & 200 & 200 & 200 & $>200$ & 200 \\
\hline L. monocytogenes & $100^{\mathrm{a}}$ & $200^{\mathrm{a}}$ & $100^{\mathrm{a}}$ & $100^{\mathrm{a}}$ & $100^{\mathrm{a}}$ & $200^{\mathrm{a}}$ & $100^{\mathrm{a}}$ & $200^{\mathrm{a}}$ \\
\hline M. luteus & $200^{\mathrm{a}}$ & 200 & 100 & 100 & 100 & 200 & $100^{\mathrm{a}}$ & 200 \\
\hline M. smegmatis & 200 & $25^{\mathrm{a}}$ & 100 & $25^{\mathrm{a}}$ & 100 & $50^{\mathrm{a}}$ & $100^{\mathrm{a}}$ & 100 \\
\hline P. aeruginosa & $>200$ & $>200$ & $>200$ & $>200$ & $>200$ & $>200$ & $>200$ & $>200$ \\
\hline R. rubra & 200 & $100^{\mathrm{a}}$ & 200 & $100^{\mathrm{a}}$ & 200 & $100^{\mathrm{a}}$ & 200 & $100^{\mathrm{a}}$ \\
\hline S. aureus & 100 & $50^{\mathrm{a}}$ & 100 & 50 & 100 & 50 & 100 & 50 \\
\hline S. faecium & 100 & $100^{\mathrm{a}}$ & $100^{\mathrm{a}}$ & $100^{\mathrm{a}}$ & $50^{\mathrm{a}}$ & $100^{\mathrm{a}}$ & 50 & $100^{\mathrm{a}}$ \\
\hline
\end{tabular}

a Bacteriostatic/fungistatic.

pure components were fungistatic at $100 \mu \mathrm{g} \mathrm{mL}^{-1}$, with the exception of $\gamma$-terpinene, which was inactive. These results agree with those obtained by Manohar et al. (2001) with an origanum essential oil which inhibited the growth of $C$. albicans. The same authors attributed the antifungal activity to carvacrol. Tampieri et al. (2005) studied the inhibition of $C$. albicans by selected essential oils and their major components, concluding that, among phenols, carvacrol is the most effective inhibitor. The antimicrobial effect of the essential oils towards L. monocytogenes is stronger than those obtained with $n$ hexane extracts, suggesting a synergistic effect. Among the pure compounds, thymol and carvacrol showed antibacterial activity. According to Yamazaki, Yamamoto, Kawai, and Inoue (2004) those compounds were found to have strong antilisterial properties. Periago, Delgado, Fernández, and Palop (2004) verified that the combination of carvacrol and cymene resulted in an increased antibacterial effect on the growth and a synergistic effect on the viability of $L$. monocytogenes compared with the natural compounds applied separately. The results obtained with this microorganism are very relevant, due to its ability to growth at refrigeration temperatures, over a wide range of $\mathrm{pH}$ values (4.4-9.6) and in the presence of high salt content (Hazzit et al., 2006) surviving mild preservation treatments, features that make it difficult to eliminate this microorganism from foods.

Thymol has a MIC value of $50 \mu \mathrm{g} \mathrm{mL}^{-1}$ towards $D$. kloeckeri, the lowest value when compared to those obtained with the other isolated compounds, essential oils and the $n$-hexane extracts, excepting for sample 2 which was also fungistatic at that concentration. D. kloeckeri is presently considered synonymous of D. hansenii, the most common species of yeast found in all types of cheeses, dairies and in brine, exhibiting high tolerance to salt and organic acids at low temperature. It may cause undesirable sensory changes in yoghurts, ice creams, fish, shellfish, due to the formation of off-odours and off-flavours.

We detected antimicrobial activity of all origanum essential oils against $R$. rubra, a common airborne contaminant of skin, lungs, urine and faeces. The essential oils were less active than the respective hexane extracts, which were all bateriostatic and showed the same activity of thymol and carvacrol. Methyl-carvacrol and $p$-cymene showed bacteriostatic effect, whereas $\gamma$-terpinene was inactive. Alma et al. (2003) did not observe antifungal activity of Origanum syriacum L. essential oil against that microorganism; however, their oil had precisely $\gamma$-terpinene as the most abundant component, with carvacrol in second place and very little thymol. The interest in the results obtained with $R$. rubra, a carotenoid-synthesizing, acid-tolerant, aerobe yeast, is its ability to use fruits and other nutrient rich foodstuffs and cause spoilage by producing off-flavours and odours and colour changes. Colonies present the aspect of pink or red slimy globules, thus degrading the economic value of beverages and yogurts.

Burt (2004) revised the antimicrobial activity of essential oils and modes of antibacterial action of essential oils, which include impairment of a variety of enzyme systems including those involved in energy production and structural component synthesis. Phenolic compounds are known to cause structural and functional damage to plasma membranes since the permeability of cell membranes depends on the hydrophobicity of the solutes that have to cross the membrane and on the composition of the membrane. Quantitative variations in the activity of essential oil are thus expected against different bacteria, especially when bacteria with different Gram are considered. Unlike many antibiotics, the hydrophobic constituents of origanum essential oils are capable of gaining access to the periplasm of Gram-negative bacteria through

Table 5

Antimicrobial activity of pure major components of Origanum and standard antibiotics.

\begin{tabular}{|c|c|c|c|c|c|c|c|}
\hline \multirow[t]{2}{*}{ Microorganisms } & \multicolumn{7}{|c|}{ Antimicrobial activity of pure major components of Origanum and standard antibiotics $\left(\mu \mathrm{g} \mathrm{mL}^{-1}\right)$} \\
\hline & Thymol & Carvacrol & Methyl-carvacrol & p-cymene & r-Terpinene & Rifampicin & 5-Fluorocytosine \\
\hline C. albicans & $100^{\mathrm{a}}$ & $50^{\mathrm{a}}$ & $100^{\mathrm{a}}$ & $100^{\mathrm{a}}$ & $>200$ & (n.t.) & 5.0 \\
\hline D. kloeckeri & $50^{\mathrm{a}}$ & $100^{\mathrm{a}}$ & $100^{\mathrm{a}}$ & $100^{\mathrm{a}}$ & $200^{\mathrm{a}}$ & (n.t.) & 5.0 \\
\hline E. coli & 100 & 100 & $>200$ & $>200$ & 200 & 1.0 & (n.t.) \\
\hline L. monocytogenes & 100 & 200 & $>200$ & $>200$ & $>200$ & 0.07 & (n.t.) \\
\hline M. luteus & 100 & 200 & $>200$ & $100^{\mathrm{a}}$ & $>200$ & 0.01 & (n.t.) \\
\hline M. smegmatis & $25^{a}$ & $200^{\mathrm{a}}$ & $50^{\mathrm{a}}$ & $100^{\mathrm{a}}$ & $>200$ & $0.5^{\mathrm{a}}$ & (n.t.) \\
\hline P. aeruginosa & 200 & $>200$ & $>200$ & $>200$ & $>200$ & $200^{a}$ & (n.t.) \\
\hline R. rubra & $100^{\mathrm{a}}$ & $100^{a}$ & $200^{\mathrm{a}}$ & $200^{\mathrm{a}}$ & $>200$ & (n.t.) & $5.0^{\mathrm{a}}$ \\
\hline S. aureus & 100 & 100 & $>200$ & $>200$ & $>200$ & 0.001 & (n.t.) \\
\hline S. faecium & $200^{a}$ & $200^{a}$ & $200^{a}$ & $200^{\mathrm{a}}$ & $>200$ & $0.5^{\mathrm{a}}$ & (n.t.) \\
\hline
\end{tabular}

(n.t.): not tested.

a Bacteriostatic/fungistatic. 
the porin proteins of the outer membrane (Helander et al., 1998). Thymol and carvacrol were also found to disintegrate the outer membrane of E. coli and Salmonella typhimurium at levels close to the MIC (Helander et al., 1998).

The structural requirements for the antimicrobial activity of carvacrol have been established (Veldhuizen, Tjeerdsma-van Bokhoven, Zweijtzer, Burt, \& Haagsman, 2006), the presence of an aromatic hydroxyl group being essential for the activity, together with moderate hydrophobicity. The same considerations can be applied to thymol: both have been previously described as able to disrupt the bacterial membrane, by affecting both the $\mathrm{pH}$ gradient and the electron flow across the membrane (Helander et al., 1998; Lambert, Skandamis, Coote, \& Nychas, 2001). This was shown to damage the cells irreversibly. The biological precursor of carvacrol, $p$-cymene, is not an effective antibacterial agent when used alone; however, when combined with carvacrol, synergism has been observed (Ultree et al., 2002). The greater efficiency of $p$-cymene incorporation into the lipid bilayer very likely facilitates the transport of carvacrol across the cytoplasmic membrane.

In the present study, the main difference in composition between essential oils and hexane extracts is the presence of significant amounts of $n$-hexacosanol. This pure compound was tested and it was found totally inactive over the ten assayed microorganisms. The long chain primary alcohols $C_{6}$ to $C_{20}$ antimicrobial activity was studied by Kubo, Muroi, and Kubo (1995) concluding that for chain lengths over $C_{16}$, no activity was found over all the tested microorganisms with a sudden drop in activity from $C_{16}$ to $C_{17}$. However, previous researchers (Moosbrugger, Bischoff, Beck, Luu, \& Borg, 1992) reported $n$-hexacosanol and similar long chain alcohols to be able to interfere with the cell membrane properties, so an effect of this compound similar to that proven to inactive $p$-cymene is not to be discarded.

We have demonstrated that origanum essential oils, their $n$ hexane extract and the predominant isolated compounds inhibit the growth of several spoilage food and human pathogenic microorganisms.

The oils studied in the present work show similar activity, even though their content in carvacrol is very small, thymol being the major phenolic in all scrutinized samples. Recent studies (Sari et al., 2006) on Origanum gladulosum from Algeria report identical findings with a fairly similar susceptibility of gram-negative and grampositive bacteria and yeast to all tested essential oil regardless of the predominance of thymol or carvacrol, and a very poor susceptibility of $P$. aeruginosa.

\section{Conclusions}

Wild 0 . vulgare subsp. virens from Madeira Island belong to a thymol rich chemotype.

The essential oils and $n$-hexane extracts have greater radical scavenging capacity than the more polar extracts, probably due to the high contents in thymol, which demonstrated the highest activity in the DPPH assay. We hope to be able to follow this trend in the antimicrobial assays, even thought the bioactivity of thymol and carvacrol over a large range of microorganisms was not very different.

All origanum samples under study show a large content in nonesterified $n$-hexacosanol, mainly accumulated in bracts and flowers, which although not showing by itself any activity as antimicrobial or antioxidant deserves to have its role in cell membrane disruption further explored.

\section{Acknowledgements}

The authors are grateful to programme INTERREG and FEDER, project Biopolis for financial support. This research was also supported by Fundação para a Ciência e a Tecnologia (FCT) with funds from the Portuguese Government (Project PEst-OE/QUI/UI0674/ 2011). Sandra Gouveia and Tatiana Weinhold are grateful to Fundação para a Ciência e Tecnologia and FEDER for PhD grants, SFRH/BD/ 24227/2005 and SFRH/BD/48148/2008. Thanks are due to Mrs Florencia Venâncio, now retired, for helpful contribution on GC analysis.

\section{References}

Alma, H. M., Yederin, A., Digrak, M., Ahmet, M., Yldirin, A., Gigrak, M., et al. (2003). Screening chemical composition and in vitro antioxidant and antimicrobial activities of the essential oils from Origanum syriacum L. growing in Turkey. Biological \& Pharmaceutical Bulletin, 26, 1725-1729.

Baydar, H., Sagdic, O., Ozkan, G., \& Karadogan, T. (2004). Antibacterial activity and composition of essential oils from Origanum, Thymbra and Satureja species with commercial importance in Turkey. Food Control, 15, 169-172.

Ben Arfa, A., Combes, S., Preziosi-Belloy, L., Gontard, N., \& Chalier, P. (2006). Antimicrobial activity of carvacrol related to its chemical structure. Letters in Applied Microbiology, 43(2), 149-154.

Benites, J., Moiteiro, C., Miguel, G., Rojo, L., López, J., Venâncio, F., et al. (2009). Composition and biological activity of the essential oil of peruvian lantana camara. Journal of The Chilean Chemical Society, 54(4), 379-384.

Bennett, J. E. (1990). Searching for the yeast connection. The New England Journal of Medicine, 323, 1766-1767.

Burt, S. (2004). Essential oils: their antibacterial properties and potential applications in foods - a review. International Journal of Food Microbiology, 94, 223-253, and references therein.

Chorianopoulos, N., Kalpoutzakis, E., Aligiannis, N., Mitaku, S., Nychas, G.-J., \& Haroutonian, S. (2004). Essential oils of Satureja, Origanum and Thymus species: chemical composition and antibacterial activities against food borne pathogens. Journal of Agricultural and Food Chemistry, 52, 8261-8267.

Cox, S. D., \& Markham, J. L. (2007). Susceptibility and intrinsic tolerance of Pseudomonas aeruginosa to selected plant volatile compounds. Journal of Applied Microbiology, 103(4), 930-936.

Ferreira, P., Gaspar, F., Sousa, C., Bernardo-Gil, G., Empis, J. A., Rouzet, M., et al. (1998). Origanum virens an oregano from Portugal. AIR - Agro Industrial Research, European Project AIR3CT93-0818. Lisboa: European Commission DG XII - Science, Research and Development, IST.

Figueredo, G., Cabassu, P., Chalchat, J.-C., \& Pasquier, B. (2006). Studies of Mediterranean oregano populations, VIII - chemical composition of essential oils of oreganos of various origins. Flavour and Fragrance Journal, 21, 134-139.

Gordon, M. H., Paiva-Martins, F., \& Almeida, M. (2001). Antioxidant activity of hydroxytyrosol acetate compared with that of other olive oil polyphenols. Journal of Agricultural and Food Chemistry, 49, 2480-2485.

Hazzit, M., Baaliouamer, A., Faleiro, M. L., \& Miguel, G. (2006). Composition of the essential oils of Thymus and Origanum species from Algeria and their antioxidant and antimicrobial activities. Journal of Agricultural and Food Chemistry, 54, 6314-6321.

Helander, I. K., Alakomi, H. L., Latva-Kala, K., Mattila-Sandholm, T., Pol, I., Smid, E. J., et al. (1998). Characterization of the action of selected essential oils on gramnegative bacteria. Journal of Agricultural and Food Chemistry, 46, 3590-3595.

Houmani, Z., Azzoudj, S., Naxakis, G., \& Skoula, M. (2002). The essential oil composition of Algerian Zaâtar: Origanum spp. and Thymus spp. Journal of Herbs, Spices \& Medicinal Plants, 9(4), 275-280.

Kubo, I., Muroi, H., \& Kubo, A. (1995). Structural functions of antimicrobial longchain alcohols and phenols. Bioorganic \& Medicinal Chemistry, 3(7), 873-880.

Kulisic, T., Radonic, A., Katalinic, V., \& Milos, M. (2004). Use of different methods for testing antioxidative activity of oregano essential oil. Food Chemistry, 85, 633-640.

Lambert, R. J. W., Skandamis, P. N., Coote, P. J., \& Nychas, G. J. E. (2001). A study of the minimum inhibitory concentration and mode of action of oregano essential oil, thymol and carvacrol. Journal of Applied Microbiology, 91(3), 453-462.

Manohar, V., Ingram, C., Gray, J., Nadeem, A. T., Echard, B. W., Bagchi, D., et al. (2001). Antifungal activities of origanum oil against Candida albicans. Molecular and Cellular Biochemistry, 228, 111-117.

Melegari, M., Severi, F., Bertoldi, M., Benvenuti, S., Circetta, G., Fortuna, I. M., et al. (1995). Chemical characterisation of essential oils of some Origanum vulgare $L$. sub-species of various origins. Rivista Italiana Eppos, 16, 21-27.

Moosbrugger, I., Bischoff, P., Beck, J. P., Luu, B., \& Borg, J. (1992). Studies on the immunological effects of fatty alcohols-I. Effects of n-hexacosanol on murine macrophages in culture. International Journal of Immunopharmacology, 14(2), 293-302.

Muroi, H., \& Kubo, I. (1996). Antibacterial activity of anacardic acid and totarol, alone and in combination with methicillin, against methicillin-resistant Staphylococcus aureus. Journal of Applied Bacteriology, 80, 387-394.

National Committee for Clinical Laboratory Standards. (1997). Reference method for broth dilution antifungal susceptibility testing of yeasts. Approved standard M27A. Wayne, Pennsylvania USA: National Committee for Clinical Laboratory Standards.

National Committee for Clinical Laboratory Standards. (2003). Methods for dilution antimicrobial susceptibility tests for bacteria that grow aerobically. Approved Standard (6th ed.). Wayne, Pennsylvania USA: NCCLS document M7-A6, ISBN $1-56238-486-4$ 
Periago, P. M., Delgado, B., Fernández, P. S., \& Palop, A. (2004). Use of carvacrol and cymene to control growth and viability of Listeria monocytogenes cells and predictions of survivors using frequency distribution functions. Journal of Food Protection, 67(7), 1408-1416.

Preuss, H., Echard, B., Dadgai, A., Talpur, N., Manohar, V., Enig, M., et al. (2005). Effects of essential oils and monolaurin on Staphylococus aureus: in vitro and in vivo studies. Toxicology Mechanisms and Methods, 15, 279-285.

Salgueiro, L. R., Cavaleiro, C., Pinto, E., Pina-Vaz, C., Rodrigues, A. G., Palmeira, A., et al. (2003). Chemical composition and antifungal activity of the essential oil of Origanum virens on Candida species. Planta Medica, 69(9), 871-874.

Sari, M., Biondi, D. M., Kaâbeche, M., Mandalari, G., D’Arrigo, M., Bisignano, G., et al. (2006). Chemical composition, antimicrobial and antioxidant activities of the essential oil of several populations of Algerian Origanum glandulosum Desf. Flavour and Fragrance Journal, 21, 890-898.

Skocibusic, M., Bezic, N., \& Dunkic, V. (2006). Phytochemical composition and antimicrobial activities of the essential oils from Satureja subspicata Vis. growing wild in Croatia. Food Chemistry, 96, 20-28.
Tampieri, M., Galuppi, R., Macchioni, F., Carelle, M., Falcioni, L., Cioni, P., et al. (2005) The inhibition of Candida albicans by selected essential oils and their major components. Mycopathologia, 159(3), 339-345.

Ultree, A., Bennink, M. H. J., \& Moezelaar, R. (2002). The phenolic hydroxyl group of carvacrol is essential for action against the food-borne pathogen Bacillus cereus. Applied and Environmental Microbiology, 68, 1561-1568.

Veldhuizen, E. J. A., Tjeerdsma-van Bokhoven, J. L. M., Zweijtzer, C., Burt, S. A., \& Haagsman, H. P. (2006). Structural requirements for the antimicrobial activity of carvacrol. Journal of Agricultural and Food Chemistry, 54(5), 1874-1879.

Yamazaki, K., Yamamoto, T., Kawai, Y., \& Inoue, N. (2004). Enhancement of antilisterial activity of essential oil constituents by nisin and diglycerol fatty acid ester. Food Microbiology, 21(3), 283-289.

Yanishlieva, N. V., Marinova, E. M., Gordon, M. H., \& Raneva, V. G. (1999). Antioxidant activity and mechanism of action of thymol and carvacrol in two lipid systems. Food Chemistry, 64, 59-66. 